\title{
LOCAL LYMPH NODE ASSAY WITH NON-RADIOISOTOPE ALTERNATIVE ENDPOINTS
}

\author{
Akiko SUDA ${ }^{1}$, Masahiro YAMASHITA ${ }^{2}$, Mitsuyuki TABEI ${ }^{3}$, Kazuhiko TAGUCHI ${ }^{4}$, \\ Hans-Werner Vohr ${ }^{5}$, Naohisa TSUTSUI ${ }^{6}$, Ritsuyoshi SUZUKI ${ }^{7}$, Katsuaki KIKUCHI ${ }^{8}$, \\ Keisuke SAKAGUCHI ${ }^{8}$, Kouki MOCHIZUKI ${ }^{9}$ and Kazuichi NAKAMURA ${ }^{10}$ \\ ${ }^{1}$ Toxicology Laboratory, Drug Metabolism and Toxicology Research Center, \\ Taisho Pharmaceutical Co., Ltd., 1-403, Yoshino-cho, Saitama-shi, Saitama 330-8530, Japan \\ ${ }^{2}$ Safety Assessment Laboratory, Pharmaceuticals Research Laboratories, Toray Industries, Inc., \\ 3-1-2 Sonoyama, Otsu, Shiga 520-0842, Japan
}

${ }^{3}$ Clinical Field Force II, Medical Development, ${ }^{4}$ Toxicology Scientific Advisor Group, Regulatory Affairs, Bayer Yakuhin, Ltd., 3-5-36 Miyahara, Yodogawa-ku, Osaka 532-8577, Japan

${ }^{5}$ Institute of Toxicology, Department of Toxicology Research, Bayer AG,

Friedrich-Ebert-Str. 217-333, Wuppertal, Germany,

${ }^{6}$ Toxicology Laboratory, Research Center, Mitsubishi Pharma Corporation, 100-5 Yana, Kisarazu-shi, Chiba 292-0812, Japan

${ }^{7}$ Immuno- \& Reproductive Toxicology Section, Safety Assessment Department, New Product Development Division, GlaxoSmithKline K.K., 43 Wadai, Tsukuba-shi, Ibaraki 300-4247, Japan

${ }^{8}$ Terumo Corporation R\&D Center, 1500 Inokuchi, Nakai-machi, Ashigarakami-gun, Kanagawa 259-0151, Japan

${ }^{9}$ Safety Research Department, Central Research Laboratories, Kaken Pharmaceutical Co., Ltd., 301 Gensuke, Fujieda, Shizuoka 426-8646, Japan

${ }^{10}$ Developmental Research Laboratories, Shionogi \& Co., Ltd., 3-1-1 Futaba-cho, Toyonaka, Osaka 561-0825, Japan

(Received August 27, 2001; Accepted June 3, 2002)

\begin{abstract}
The local lymph node assay has recently been accepted by regulatory agencies as a standalone alternate method for predicting allergic contact dermatitis. To compare the sensitivity of non-radioisotope methods with that of the standard assay, we determined if these modified methods would affect evaluation of sensitization potency. For this reason, we used 2,4-dinitrochlorobenzene (DNCB) and benzocaine for different sensitizing criteria.

Female CBA mice were treated for 3 days with a test compound or vehicle applied to each side of both ears. Bilateral auricular lymph node proliferative activity was assessed by the following endpoints with incorporation of ${ }^{3} \mathrm{H}$-methyl thymidine (3H-TdR), bromodeoxyuridine (BrdU) in vivo, and $\mathrm{BrdU}$ ex vivo, IL-2 production, and proliferating cell nuclear antigen (PCNA) expression. Ear thickness was also tested.

The strong sensitizer DNCB was detectable by any of the non-radioisotope endpoints as well as by radioisotope-dependent standard assay. On the other hand, when evaluating the weak sensitizer benzocaine, significant changes were evident in BrdU incorporation ex vivo and in vivo, and IL-2 production. We believe that these non-radioisotope methods can assess allergic contact dermatitis caused by chemicals even in the laboratory, where it can be difficult to handle radioisotopes.
\end{abstract}

KEY WORDS: Local lymph node assay (LLNA), Non-radioisotope method, Skin sensitizer, DNCB, Benzocaine 


\section{INTRODUCTION}

The murine local lymph node assay (LLNA) is a new test method used to assess allergic contact dermatitis caused by chemicals, as first proposed by Kimber et al. in 1989. This method is already mentioned in the OECD Guideline 406 (1992) as a screening test. Since then, the method has been validated and accepted as a stand-alone method by regulatory agencies (Food and Drug Administration, Environmental Protection Agency, Occupational Safety and Health Administration and Consumer Product Safety Commission). Details of this validation and a review of associated work have been published (Chamberlain and Basketter, 1996; Basketter et al., 1996, 1998; NIH Publication, 1999).

The LLNA standard method is as follows: $25 \mu \mathrm{l} /$ ear of the appropriate dilution of the test substance or vehicle alone was applied to the dorsum of both ears of female CBA mice daily for 3 consecutive days. Four days after the first application, mice were given, via the tail vein, phosphate-buffered saline (PBS) containing ${ }^{3} \mathrm{H}$-methyl thymidine (3H-TdR). Five hours later, draining auricular lymph nodes were excised. Incorporation of $3 \mathrm{H}-\mathrm{TdR}$ was measured using $\beta$-scintillation counting for each mouse. The stimulation index (SI) is the ratio of the mean dpm/mouse for the test substance treatment group versus the mean $\mathrm{dpm} /$ mouse for the vehicle treatment control group. The decision process to identify a positive response should include $\mathrm{SI} \geq 3$, statistical significance and dose response information.

For decades, the guinea pig maximization test (GPMT) and the Buehler assay (BA) have been the standards used to assess the allergic contact dermatitis potential of chemicals. When compared with these methods, LLNA has several advantages in that it provides quantitative data, fewer animals are needed, color compounds can be evaluated, and much less time is needed. However, the weakness of LLNA is false negative results with weak sensitizers predicted by GPMT. Furthermore, the use of radioisotopes $\left({ }^{3} \mathrm{H}-\right.$ methyl thymidine, ${ }^{125}$ I-iododeoxyuridine) in LLNA standard protocol renders the method inconvenient for routine screening testing.

To avoid the use of radioactive labeling, many investigators have developed non-radioisotope methods in the LLNA. Boussiquet-Levoux et al. (1995) reported that a proliferating response of lymph node cells (LNC) in mice was assessed by immunohistochemistry, using bromodeoxyuridine (BrdU). The proliferation of LNC was also determined by the flow cytometric (FCM) analysis of proliferating cell nuclear antigen (PCNA) (Kuhn et al., 1995). Other than proliferating responses, several functional approaches were reported, including phenotypic analysis of LNC subpopulations: B220 positive cells (Sikorski et al., 1996), CD3 positive cells and CD25 positive cells (De Silva et al., 1993), CD62L $\mathrm{L}^{\mathrm{lo}} / \mathrm{CD} 44^{\mathrm{hi}}$ double positive cells (Gerberick et al., 1997, 1999a), CD86 positive cells, and I-A ${ }^{\mathrm{k}}$ positive cells (Gerberick et al., 1999b). These methods, based on the FCM analysis, could distinguish a contact allergen from irritants. Production of Th1 cytokines IL-2 (Hatao et al., 1995), and IL-6 (Dearman et al., 1994) were assessed, using a competitive reverse transcriptase-polymerase chain reaction (cRT-PCR) or enzyme-linked immunosorbent assay (ELISA). Cytokine production was increased by strong allergens. Hariya et al. (1999) reported that IL-2 production with lymph node weight and CD4 positive subset ratio in LNC improved sensitivity. Homey et al. (1998) and Vohr et al. (2000) presented an integrated model for differentiating skin reaction (IMDS), which assesses ear swelling and cell proliferation in lymph nodes.

Eight member companies of the Japan Pharmaceutical Manufacturers Association (JPMA) collaboratively studied the following non-radioisotope methods: BrdU incorporation ex vivo and in vivo, IL-2 production, PCNA expression, and IMDS. These methods were compared with the radioisotope-dependent standard LLNA.

\section{MATERIALS AND METHODS}

\section{Test materials}

2,4-Dinitrochlorobenzene (DNCB) was obtained from Sigma Chemical Co., (St. Louis, MO, USA), and 4-amino benzoic acid ethyl ester (benzocaine) from Sigma or Tokyo Chemical Industry Co. (Tokyo, Japan). These materials were dissolved in 4:1 acetone/ olive oil (AOO), at concentrations of $0.01 \%, 0.05 \%$, $0.13 \%, 0.25 \%$ or $0.5 \%$ for $\mathrm{DNCB}$, and $2.5 \%, 5 \%$ or $10 \%$ for benzocaine.

\section{Animals}

Female 7-8 week-old CBA mice were purchased from Charles River Japan (Atsugi, Japan). Only Laboratory $\mathrm{H}$ purchased animals from Bomoltgardt, Ry. (Denmark). All animals were used at age 8-9 weeks. Housing and feeding conditions were set according to the standard of each laboratory. Each group included 6 animals. 
LLNA with non-radioisotope alternative endpoints.

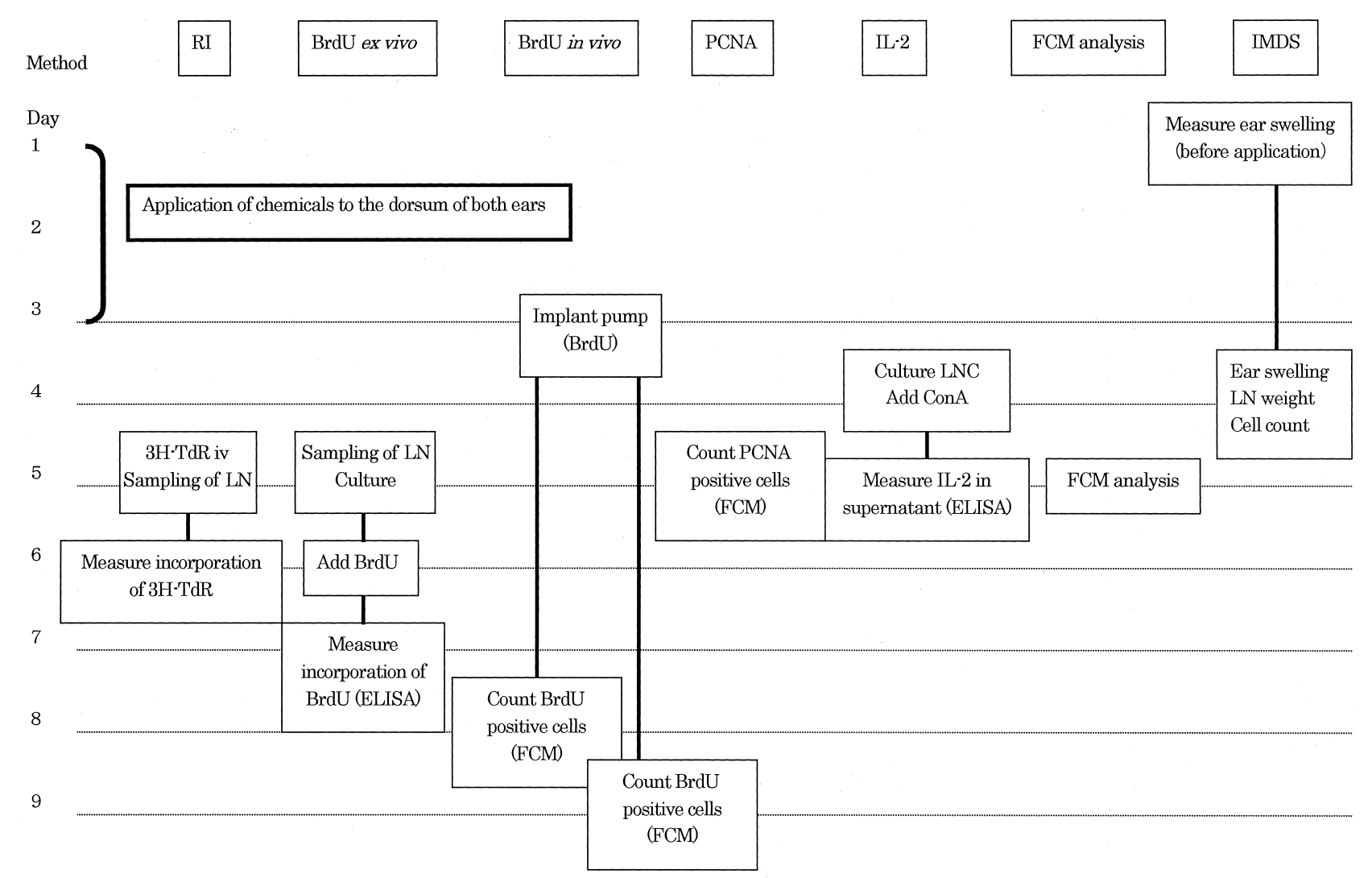

Fig. 1. Schedules for various modified local lymph node assays.

\section{Sensitization}

Weighed mice were individually identified prior to dermal applications. For mice in the test substance treatment group, we applied $25 \mu \mathrm{l} / \mathrm{ear}$ of the test substance to the dorsum of both ears of mice, and in the control group we applied the same volume of the vehicle alone to the dorsum of both ears. Treatment was given daily for 3 consecutive days (days 1-3).

Fig. 1 shows the schedule of each method.

\section{LLNA (standard RI method)}

On Day 5 , mice were injected via the tail vein with $250 \mu \mathrm{l}$ of phosphate-buffered saline (PBS) containing $740 \mathrm{kBq}$ of ${ }^{3} \mathrm{H}$-methyl thymidine (3H-TdR, NEN Life Science Products, Inc., MA, USA). Five hours later, these mice were killed and bilateral draining lymph nodes for each animal were excised and pooled in PBS. Single cell suspensions of lymph node cells (LNC) were prepared by gentle mechanical separation through a 380-mesh nylon filter (Becton Dickinson Labware, NJ, USA). LNC were pelleted by centrifugation at $190 \times \mathrm{g}$ for $10 \mathrm{~min}$, washed twice with an excess of PBS and precipitated with $3 \mathrm{ml}$ of $5 \%$ trichloroacetic acid (TCA) overnight at $4^{\circ} \mathrm{C}$. Pellets were resuspended in $1 \mathrm{ml}$ TCA and transferred to 10 $\mathrm{ml}$ of scintillation fluid (Ultima Gold LLT, Packard Instrument Company, CT, USA). Incorporation of $3 \mathrm{H}-$ TdR was measured using a $\beta$-scintillation counter (LS 6000TA, Beckman, FL, USA) as disintegration per minute (dpm) for each mouse. This method was carried out in Laboratory A.

\section{BrdU incorporation (ex vivo)}

Cell proliferation ELISA system, version 2 (code RPN250, BIOTRAK ${ }^{\mathrm{TM}}$, Amersham Pharmacia Biotech, Tokyo, Japan) was used.

On Day 5, mice were killed and bilateral draining auricular lymph nodes were excised. Single cell suspensions were prepared for $5 \times 10^{6}$ cells $/ \mathrm{ml}$ with 25 mM HEPES-RPMI 1640 medium (10\% FBS, $100 \mu \mathrm{g} /$ $\mathrm{ml}$ penicillin, $100 \mathrm{U} / \mathrm{ml}$ streptomycin) in a 96-well microplate in a final volume of $100 \mu \mathrm{l} / \mathrm{well}$, and cultured for $18 \mathrm{hr}\left(37^{\circ} \mathrm{C}, 5 \% \mathrm{CO}_{2}\right)$. Then $100 \mathrm{mM} \mathrm{BrdU}$ labeling solution was added $10 \mu \mathrm{l} /$ well. Cells were cul- 
tured for $20 \mathrm{hr}\left(37^{\circ} \mathrm{C}, 5 \% \mathrm{CO}_{2}\right)$ to incorporate the BrdU. Cells were washed 3 times with PBS, and dried $\left(60^{\circ} \mathrm{C}, 1 \mathrm{hr}\right)$. Cell fixative, including ethanol, was added at $200 \mu \mathrm{l} /$ well, followed by incubation at room temperature for $30 \mathrm{~min}$. After removing the fixative, blocking buffer (containing 1\% BSA in $50 \mathrm{mM}$ Tris$\mathrm{HCl}, 150 \mathrm{mM} \mathrm{NaCl}, \mathrm{pH}$ 7.4) was added at $200 \mu \mathrm{l} /$ well. Peroxidase-labeled anti-BrdU antibody working solution was added at $100 \mu \mathrm{l} /$ well, followed by incubation for $90 \mathrm{~min}$ at room temperature. Samples were washed 3 times with PBS, and tetramethylbenzidine (TMB) substrate was added at $100 \mu \mathrm{l} /$ well, followed by incubation at room temperature for $20 \mathrm{~min}$. To stop the reaction, $1 \mathrm{~mol} / \mathrm{L} \mathrm{H}_{2} \mathrm{SO}_{4}$ was added at $25 \mu \mathrm{l} / \mathrm{well}$, and absorbance was determined in a plate reader at $450 \mathrm{~nm}$ within 5 min This method was carried out in Laboratories $\mathrm{B}$ and $\mathrm{C}$.

\section{BrdU incorporation (in vivo)}

After the third application of the test substance or vehicle, the ALZET micro-osmotic pump (model 1007D, ALZA Co., Palo Alto, CA, USA), filled with bromodeoxyuridine (BrdU, Sigma) solution, was implanted subcutaneously in the abdomen. BrdU was dissolved with $50 \%$ dimethyl sulfoxide in physiological saline at 150 or $300 \mathrm{mg} / \mathrm{ml}$. On Day 8 or 9 , bilateral draining auricular lymph nodes were excised and single cell suspensions of LNC were prepared by gentle mechanical disaggregation. LNC were suspended in Dulbecco's minimum essential medium (DMEM) with $1 \%$ FCS added. Cells were then washed in DMEM (centrifuge $500 \times \mathrm{g}$ for $15 \mathrm{~min} 2$ times). After the first washing, the cell suspension was filtered through a cell strainer. Anti-Fc receptor antibody was added to the cell suspension in $200 \mu \mathrm{l}$ DMEM, mixed and then stored at room temperature for $5 \mathrm{~min}$. In one laboratory, fluorescence-labeled anti-B220 antibody (clone: RA3-6B2, Pharmingen, San Diego, CA, USA) or antiCD3 antibody (clone: 145-2C11, Pharmingen) was added. In another laboratory, fluorescence-labeled anti-B220 antibody (clone: RA3-6B2, Pharmingen), anti-CD4 antibody (clone: RM4-5, Pharmingen) or anti-CD8 antibody (clone: 53-6.7, Pharmingen) was added and the preparation stored on ice in the dark for $30 \mathrm{~min}$. Cells were then washed twice in DMEM. A pellet loosened by vortex was suspended in iced $250 \mu$ l saline. A few drops of iced $95 \%$ ethanol were added and the tubes were thoroughly shaken. The treatment was repeated until $600 \mu \mathrm{l}$ of ethanol had been added. After incubation at $4^{\circ} \mathrm{C}$ for $30 \mathrm{~min}$, the preparation was centrifuged at $3000 \times \mathrm{g}$ for $3 \mathrm{~min}$, the supernatant was aspirated, and cells were resuspended with $100 \mu \mathrm{l}$ PBS. Cells were fixed and permeabilized in PBS containing $1 \%$ paraformaldehyde and $0.01 \%$ Tween 20 at room temperature for $30 \mathrm{~min}$. Cells were then washed twice in PBS (centrifuge $3000 \times \mathrm{g}$ for $3 \mathrm{~min}$ ). BrdU was then detected as described (Penit and Vasseur, 1993). Two hundred $\mu \mathrm{l}$ of $50 \mathrm{U} / \mathrm{ml}$ DNase/IMDM was added and the preparation was stored for $10 \mathrm{~min}$. Cells were then placed in a 96-well plate. Fluorescence-labeled antiBrdU antibody (clone: B44, Becton Dickinson, San Jose, CA, USA) was added to each well and the preparation was stored at $4^{\circ} \mathrm{C}$ for $20 \mathrm{~min}$. Cells were then washed twice in PBS. Immunofluorescence was analyzed using a FACScan flow cytometer (Becton Dickinson) and the Cell Quest program. This method was carried out in Laboratories D and E.

\section{PCNA expression}

On Day 5, mice were killed and bilateral draining auricular lymph nodes were excised. LNC suspensions were added to the test tube $\left(1 \times 10^{6}\right.$ cells/tube $)$ which was centrifuged at $425 \times \mathrm{g}$ for $5 \mathrm{~min}$. Pellets were suspended with $500 \mu \mathrm{l}$ of $1 \%$ paraformaldehyde, and kept at room temperature for $5 \mathrm{~min}$. One $\mathrm{ml}$ of ice-cold PBS was added to each tube, centrifuged and the supernatant was aspirated. Pellets were resuspended with $1 \mathrm{ml}$ of cold methanol $\left(-20^{\circ} \mathrm{C}\right)$, and kept at room temperature for $10 \mathrm{~min}$. Each tube was centrifuged and the supernatant was aspirated. These test tubes were centrifuged twice with $0.1 \%$ Triton X100. Fifty $\mu \mathrm{L}$ of FITC-conjugated anti-PCNA antibody $(25 \mu \mathrm{g} / \mathrm{ml}$ in $0.1 \%$ Triton X100, clone: 19F4, Boehringer-Mannheim Biochemicals, Germany) was added and the preparation kept at room temperature for $15 \mathrm{~min}$ protected from light. Cells were washed twice in $0.1 \%$ Triton X100. Labeled cells were analyzed using a flow cytometer (EPICS XL, BECKMAN COULTER, Florida, USA). This method was carried out in Laboratory F.

\section{IL-2 production}

On Day 4, mice were killed and bilateral auricular lymph nodes were excised. LNC were suspended in RPMI 1640 medium supplemented with 10\% FCS, 25 $\mathrm{mM}$ HEPES, $100 \mu \mathrm{g} / \mathrm{ml}$ penicillin and $100 \mathrm{U} / \mathrm{ml}$ streptomycin at the concentration of $2 \times 10^{6}$ cells $/ \mathrm{ml}$. An aliquot of $200 \mu \mathrm{l}$ of LNC suspension was seeded into each well of a 96-well tissue culture plate. Concanavalin A (ConA, Sigma) was added to each well at the final concentration of $2 \mu \mathrm{g} / \mathrm{ml}$. LNC were cultured for $24 \mathrm{hr}\left(37^{\circ} \mathrm{C}, 5 \% \mathrm{CO}_{2}\right)$. The amount of IL-2 released 
LLNA with non-radioisotope alternative endpoints.

into the supernatant was measured using an IL-2 ELISA kit (Endogen Inc., MA, USA). This method was carried out in Laboratory G.

Flow cytometric (FCM) analysis of lymphocyte subsets

On Day 5, mice were killed and bilateral auricular lymph nodes were excised. Single cell suspensions were prepared for each group. The following fluorescence-labeled monoclonal antibodies were used to detect lymphocyte subpopulations. Anti-mouse CD3 antibody (clone: 145-2C11, Pharmingen) was used for detection of mature $\mathrm{T}$ lymphocytes, anti-mouse CD4 antibody (clone: RM4-4, Pharmingen) for detection of $\mathrm{T}$ helper cells, anti-mouse CD8 antibody (clone: 536.7, Pharmingen) for detection of $\mathrm{T}$ suppressor/cytotoxic cells, anti-mouse B220 antibody (clone: RA36B2, Pharmingen) for detection of B lymphocytes, and anti-mouse CD25 antibody (clone: 7D4, Pharmingen) for detection of activated $\mathrm{T}$ and $\mathrm{B}$ lymphocytes. Labeled cells were analyzed using a FACScan flow cytometer (Becton Dickinson). This method was carried out in Laboratory G.

\section{Integrated model for differentiating skin reaction (IMDS)}

Before initial treatment (Day 1) and the day after the final treatment (Day 4), ear thickness was measured and mean ear swelling was calculated. On Day 4, bilateral auricular lymph nodes were removed and pooled for each individual animal. After weighing the lymph nodes, single cell suspensions were prepared for each mouse. Using these suspensions, LNC were counted, using an automatic cell counter, and cellularity index was calculated. In addition, cells were labeled by fluorescence-labeled anti-B220 antibody (clone: RA3-6B2, Pharmingen), anti-CD69 antibody (clone: H1.2F3, Pharmingen), which is expressed on very early activated lymphocytes, and anti-I-A antibody (clone: M5/114, Boehringer-Mannheim Biochemicals), which reacts with the mouse MHC Class II molecule. FCM analysis was performed using FACScan equipment (Becton Dickinson). To differentiate between allergic and irritant potential, Differentiation Indices (DI) were calculated, as described (Homey et al., 1998), using the following formulas. This method was carried out in Laboratory $\mathrm{H}$.

$\%$ of maximal increase in lymph
node cell count index $=\frac{\mathrm{LN} \text { index }-1}{4} \times 100$
$\%$ of maximal ear swelling $=\frac{\text { ear swelling }(\mathrm{mm})}{15 \times 0.01(\mathrm{~mm})} \times 100$

$\mathrm{DI}=\frac{\% \text { of maximal increase in lymph node cell count index }}{\% \text { of maximal ear swelling }}$

DI $<1 \cong$ irritant potential $\quad$ DI $>1 \cong$ allergic potential

\section{Cellularity}

Seven laboratories calculated cellularity indices from comparisons of cell counts of each test substance treatment group and the control AOO treatment group. In Laboratories B, C and D, cells were counted manually using a hemocytometer. In Laboratories E, F, G and $\mathrm{H}$, cells were counted using an automatic cell counter.

\section{Statistical analysis}

For each method, the stimulation index (SI) was the ratio of the mean of actual measurements for each test substance versus that of the AOO control group. Each test substance treatment group and the AOO treatment control group were compared by Dunnett's multiple comparison test (Dunnett, 1955) using the SAS program.

\section{RESULTS}

\section{LLNA (standard RI method)}

The results are shown in Table 1. SIs of DNCB were $1.31,1.99,10.87,90.86$ and 145.43 in the $0.01 \%$, $0.05 \%, 0.13 \%, 0.25 \%$ and $0.5 \%$ groups, respectively. Dose-dependent increases were evident, and statistically significant increases were observed in the $0.25 \%$ and $0.5 \%$ groups. On the other hand, SIs of benzocaine were $1.66,0.83$ and 2.45 in the $2.5 \%, 5 \%$ and $10 \%$ groups, respectively. Dose-dependent increases and statistically significant increases were not observed.

\section{BrdU incorporation (ex vivo)}

The results are shown in Table 1. In the two laboratories, SIs of the $0.25 \%$ DNCB group were 4.14 and 2.47. However, at concentrations lower than $0.25 \%$ DNCB, contact hypersensitivity-eliciting potential was not detected. As to benzocaine, there was no significant change between the benzocaine groups and AOO group in one laboratory. In another laboratory, statistically significant increases were observed in the $5 \%$ and $10 \%$ benzocaine groups. 


\section{A. SUDA et al.}

Table 1. Stimulation indices determined by various modified local lymph node assays.

\begin{tabular}{|c|c|c|c|c|c|c|}
\hline \multirow{2}{*}{ Substance } & \multicolumn{2}{|c|}{ 3H-TdR incorporation } & \multicolumn{2}{|c|}{ BrdU incorporation (ex vivo)-1 } & \multicolumn{2}{|c|}{ BrdU incorporation (ex vivo)-2 } \\
\hline & $(\mathrm{dpm})$ & Index & O.D. $450 \mathrm{~nm}$ & Index & O.D. $450 \mathrm{~nm}$ & Index \\
\hline $\mathrm{AOO}$ & $94.5 \pm 17.8$ & 1.00 & $0.16 \pm 0.02$ & 1.00 & $0.15 \pm 0.05$ & 1.00 \\
\hline $0.01 \% \mathrm{DNCB}$ & $124.6 \pm 55.5$ & 1.31 & $0.18 \pm 0.03$ & 1.15 & $0.17 \pm 0.03$ & 1.20 \\
\hline $0.05 \% \mathrm{DNCB}$ & $188.4 \pm 74.3$ & 1.99 & $0.25 \pm 0.07$ & 1.50 & $0.19 \pm 0.05$ & 1.34 \\
\hline $0.13 \% \mathrm{DNCB}$ & $1673 \pm 1186$ & 10.87 & - & - & - & - \\
\hline $0.25 \% \mathrm{DNCB}$ & $10890.4 \pm 214415 * *$ & 90.86 & $0.68 \pm 0.09 * *$ & 4.14 & $0.36 \pm 0.18 * *$ & 2.47 \\
\hline $0.50 \% \mathrm{DNCB}$ & $17431 \pm 1227 * *$ & 145.43 & - & - & - & I \\
\hline AOO & $119.9 \pm 22.3$ & 1.00 & $0.16 \pm 0.02$ & 1.00 & $0.15 \pm 0.05$ & 1.00 \\
\hline $2.50 \%$ Benzocaine & $199.4 \pm 217.6$ & 1.66 & $0.19 \pm 0.12$ & 1.18 & $0.21 \pm 0.03$ & 1.48 \\
\hline $5.00 \%$ Benzocaine & $99.4 \pm 28.8$ & 0.83 & $0.12 \pm 0.02$ & 0.72 & $0.26 \pm 0.01 * *$ & 1.81 \\
\hline $10.00 \%$ Benzocaine & $293.8 \pm 343.8$ & 2.45 & - & - & $0.24 \pm 0.05 * *$ & 1.68 \\
\hline
\end{tabular}

\begin{tabular}{|c|c|c|c|c|c|c|}
\hline \multirow[b]{2}{*}{ Substance } & \multicolumn{2}{|c|}{ BrdU incorporation (in vivo)-1 } & \multicolumn{2}{|c|}{ BrdU incorporation (in vivo)-2 } & \multicolumn{2}{|c|}{ PCNA expression } \\
\hline & $\begin{array}{c}\text { Number of cells incorporating } \\
\operatorname{BrdU}\left(\times 10^{4}\right)\end{array}$ & Index & $\begin{array}{c}\text { Number of cells incorporating } \\
\operatorname{BrdU}\left(\times 10^{4}\right)\end{array}$ & Index & $\begin{array}{l}\text { Number of PCNA- } \\
\text { positive cells }\left(\times 10^{4}\right)\end{array}$ & Index \\
\hline $\mathrm{AOO}$ & $13.2 \pm \quad 5.7$ & 1.00 & $54.4 \pm 13.3$ & 1.00 & $2.1 \pm 0.7$ & 1.00 \\
\hline $0.01 \% \mathrm{DNCB}$ & $31.7 \pm 20.6$ & 2.40 & $65.8 \pm 18.1$ & 1.21 & $3.3 \pm 0.7$ & 1.59 \\
\hline $0.05 \% \mathrm{DNCB}$ & $60.9 \pm 30.2$ & 4.62 & $87.5 \pm 22.9$ & 1.61 & $5.3 \pm 2.3$ & 2.51 \\
\hline $0.13 \% \mathrm{DNCB}$ & - & - & - & - & - & - \\
\hline $0.25 \% \mathrm{DNCB}$ & $494.4 \pm 245.8 * *$ & 37.50 & $494.0 \pm 75.9 * *$ & 9.08 & $71.8 \pm 10.3 * *$ & 34.17 \\
\hline $0.50 \% \mathrm{DNCB}$ & - & - & - & - & - & - \\
\hline $\mathrm{AOO}$ & $13.2 \pm 5.7$ & 1.00 & $43.1 \pm 8.6$ & 1.00 & $2.1 \pm 0.7$ & 1.00 \\
\hline $2.50 \%$ Benzocaine & $19.2 \pm \quad 9.14$ & 1.46 & $87.1 \pm 27.6 *$ & 2.02 & $3.4 \pm 0.8$ & 1.63 \\
\hline $5.00 \%$ Benzocaine & $25.4 \pm 14.6$ & 1.93 & $122.9 \pm 48.4 * *$ & 2.85 & $2.4 \pm 0.4$ & 1.12 \\
\hline $10.00 \%$ Benzocaine & $18.6 \pm 10.4$ & 1.41 & $96.7 \pm 23.1 *$ & 2.24 & $3.3 \pm 0.6$ & 1.56 \\
\hline
\end{tabular}

\begin{tabular}{|c|c|c|c|c|c|c|}
\hline \multirow{2}{*}{ Substance } & \multicolumn{2}{|c|}{ IL-2 production } & \multicolumn{2}{|l|}{ Lymph node weight } & \multirow{2}{*}{$\begin{array}{c}\text { Ear swelling } \\
\text { Index }\end{array}$} & \multirow{2}{*}{ DI (IMDS) } \\
\hline & $(\mathrm{pg} / \mathrm{ml})$ & Index & (mg) & Index & & \\
\hline $\mathrm{AOO}$ & $1529 \pm 783$ & 1.00 & $4.69 \pm 0.27(4.38 \pm 0.87)$ & 1.00 & & \\
\hline $0.01 \%$ DNCB & $2104 \pm 693$ & 1.38 & $4.92 \pm 0.40$ & 1.05 & 1.01 & 1.08 \\
\hline $0.05 \%$ DNCB & $2562 \pm 1253$ & 1.68 & $4.71 \pm 0.41$ & 1.00 & 0.99 & n.c. \\
\hline $0.13 \%$ DNCB & - & - & $(5.29 \pm 1.25)$ & 1.21 & 1.02 & 2.73 \\
\hline $0.25 \%$ DNCB & $18475 \pm 6922 * *$ & 12.08 & $(6.80 \pm 1.16)$ & 1.55 & 1.01 & 7.50 \\
\hline $0.50 \% \mathrm{DNCB}$ & - & - & $(8.98 \pm 2.99 * * *)$ & 2.05 & 1.17 & 2.79 \\
\hline $\mathrm{AOO}$ & $1529 \pm 783$ & 1.00 & $4.38 \pm 0.87$ & 1.00 & & \\
\hline $2.50 \%$ Benzocaine & $2978 \pm 1631$ & 1.95 & $5.45 \pm 0.65 *$ & 1.25 & 1.05 & 1.07 \\
\hline $5.00 \%$ Benzocaine & $4668 \pm 1556 * *$ & 3.05 & $4.04 \pm 0.66$ & 0.93 & 1.05 & n.c. \\
\hline $10.00 \%$ Benzocaine & $2164 \pm 1260$ & 1.42 & $5.56 \pm 0.79 *$ & 1.28 & 0.99 & 1.86 \\
\hline
\end{tabular}

Each value represents the mean \pm S.D. (-: Not examined). In the lymph node weight, (the mean \pm S.D.) represents data, which were obtained using the same method on another day. $\times 10^{4}$ represents multiplication of the number of cells by 10000 . Index is the ratio of the mean of actual measurements for each test substance treatment group against that of the AOO treatment control group. Each test substance treatment group and the AOO treatment control group were compared by Dunnett's multiple comparison.

$*: \mathrm{p}<0.05, * *: \mathrm{p}<0.01, * * *: \mathrm{p}<0.001$.

- : not examined, n.c.: not calculated. 
LLNA with non-radioisotope alternative endpoints.

\section{BrdU incorporation (in vivo)}

The results are shown in Table 1. In one laboratory, the BrdU positive cell count indices of DNCB on Day 8 were $2.40,4.62$ and 37.50 in the $0.01 \%, 0.05 \%$ and $0.25 \%$ groups, respectively. In another laboratory, indices on Day 9 were $1.21,1.61$ and 9.08 in the $0.01 \%, 0.05 \%$ and $0.25 \%$ groups, respectively. In both of these laboratories, dose-dependent increases were evident, and a statistically significant increase was observed in the $0.25 \%$ group. As to benzocaine, in the former laboratory, BrdU positive cells did not increase. The indices of benzocaine were below 2 and dosedependent increases were nil. In the latter laboratory, benzocaine induced statistically significant increases in the number of BrdU positive cells at all three concentrations, with no dose dependence.

In FCM analysis, BrdU and B220 or CD3; 2 color staining (Table 2), some differences in distribution of increasing cells were found in the $0.25 \%$ DNCB group. Cell count indices for 'BrdU+/CD3+' and 'BrdU-/CD3+' were 38.69 and 9.65 (cell \% indices: 2.46 and 0.66), respectively. Cell count indices for 'BrdU+/B220+' and 'BrdU-/B220+' were 21.21 and 26.12 (cell \% indices: 1.67 and 1.94), respectively. It was assumed that increasing cells that were BrdU negative had proliferated before the pump was implanted or delivered to the auricular lymph nodes. Table 3 shows the results of 2-color staining with BrdU and $\mathrm{B} 220$ or CD4 or CD8 in the DNCB group. The cell count index of 'BrdU+/CD4+ and BrdU+/CD8+' was 8.47 , and that of 'BrdU+/B220+' was 6.71 in the $0.25 \%$ group.

\section{PCNA expression}

The results are shown in Table 1. SIs of the DNCB groups (at concentrations of $0.01 \%, 0.05 \%$ and $0.25 \%$ ) were $1.59,2.51$ and 34.17 , respectively. At concentration of $0.25 \%$, there was a significant increase. SIs of the benzocaine groups (at concentrations of $2.5 \%, 5 \%$ and $10 \%$ ) were $1.63,1.12$ and 1.56 , respectively. There were no significant differences between the benzocaine groups and the AOO group.

\section{IL-2 production}

The results are shown in Table 1 . SIs of the DNCB groups (at concentrations of $0.01 \%, 0.05 \%$ and $0.25 \%$ ) were $1.38,1.68$ and 12.08 , respectively. At concentration of $0.25 \%$, the increase was significant. SIs of benzocaine groups (at concentrations of $2.5 \%$, $5 \%$ and $10 \%$ ) were $1.95,3.05$ and 1.42 , respectively. At a concentration of 5\%, the increase was significant.

\section{FCM analysis of lymphocyte subsets}

The results are shown in Table 4. The percentages of B220 positive cells and CD25+ cells increased dosedependently in the DNCB groups. On the other hand, the percentages of CD3+ cells and CD4+ cells decreased, and those of CD8+ cells were unchanged. Lymphocyte subpopulations were unchanged in the benzocaine groups.

\section{Integrated model for differentiating skin reaction (IMDS)}

In the laboratory where IMDS was measured, DNCB showed a dose-dependent increase in LN weight (Table 1) and cell count indices (see Cellularity-7 in Table 6). Indices were 1.21, 1.55, 2.05 for weight and 1.71, 2.95, 3.52 for cell count in the $0.13 \%$, $0.25 \%$ and $0.5 \%$ groups, respectively. In ear swelling index, a slight increase was found at a concentration of $0.5 \%$, but not so at $0.13 \%$ or $0.25 \%$. Dls of DNCB were $2.73,7.50$ and 2.79 (lower due to increased ear swelling [cf. METHOD]) in the $0.13 \%, 0.25 \%$ and $0.5 \%$ groups, respectively. Since DI showed values $>1$ for all concentrations tested, DNCB was an allergic compound. In FCM analysis, increases of B220+/I-A+ and CD69+/I-A+ cells were observed in the DNCB groups (Table 5). In addition, at $0.5 \%$, ear swelling index showed a slight increase. Therefore, the weak irritant potential of DNCB at higher concentrations was determined using this test system as well.

Benzocaine at concentrations of $2.5 \%$ and $10 \%$ showed significant increases in $\mathrm{LN}$ weight. Indices were $1.25,0.93,1.28$ for weight and $1.28,1.03,1.47$ for cell count in the $2.5 \%, 5 \%$ and $10 \%$ groups, respectively. There were no changes in ear swelling index at any concentration used. Since DI at $10 \%$ was 1.86 , it was suggested that the response after treatment of benzocaine was caused by its potential as an allergic substance.

\section{Cellularity}

The results are shown in Table 6. In all laboratories, statistically significance increases were observed in the $0.25 \%$ DNCB group. As for benzocaine, in two laboratories, statistically significance increases were observed (5\% group in one laboratory and the $2.5 \%$, $5 \%$ and $10 \%$ groups in another laboratory).

\section{DISCUSSION}

In the study presented here, non-radioisotope methods were compared with the radioisotope-depen- 


\section{A. SUDA et al.}

Table 2. Flow cytometric analysis for BrdU incorporation in lymph node cells-1.

\begin{tabular}{|l|cc|c|c|c|c|c|c|}
\hline \multirow{2}{*}{ Substance } & \multicolumn{4}{|c|}{ BrdU+/B220+ } & \multicolumn{4}{|c|}{ BrdU+/CD3+ } \\
\cline { 2 - 8 } & $(\%)$ & Index & $\left(\times 10^{4}\right)$ & Index & $(\%)$ & \multicolumn{1}{|c|}{ Index } & $\left(\times 10^{4}\right)$ \\
\hline \hline AOO & $1.69 \pm 1.06$ & 1.00 & $3.39 \pm 2.62$ & 1.00 & $6.05 \pm 2.40$ & 1.00 & $11.03 \pm 4.51$ & 1.00 \\
$0.01 \%$ DNCB & $1.59 \pm 0.52$ & 0.94 & $5.64 \pm 2.84$ & 1.66 & $5.72 \pm 1.57$ & 0.95 & $24.32 \pm 22.00$ & 2.20 \\
$0.05 \%$ DNCB & $1.37 \pm 0.48$ & 0.81 & $8.33 \pm 2.32$ & 2.46 & $7.24 \pm 3.25$ & 1.20 & $51.75 \pm 40.56$ & 4.69 \\
$0.25 \%$ DNCB & $2.82 \pm 0.73 *$ & 1.67 & $71.91 \pm 32.81 * *$ & 21.21 & $14.90 \pm 2.73 * *$ & 2.46 & $426.79 \pm 292.57 * * \mid 38.69$ \\
& & & & & & & & \\
$2.50 \%$ Benzocaine & $1.26 \pm 0.27$ & 0.75 & $4.62 \pm 2.11$ & 1.36 & $4.17 \pm 1.05$ & 0.69 & $15.93 \pm 8.23$ & 1.44 \\
$5.00 \%$ Benzocaine & $1.21 \pm 0.31$ & 0.72 & $5.30 \pm 1.65$ & 1.56 & $4.79 \pm 3.33$ & 0.79 & $22.34 \pm 15.01$ & 2.03 \\
$10.00 \%$ Benzocaine & $1.34 \pm 0.51$ & 0.79 & $3.55 \pm 0.86$ & 1.05 & $6.65 \pm 2.04$ & 1.10 & $19.85 \pm 10.53$ & 1.80 \\
\hline
\end{tabular}

\begin{tabular}{|l|c|c|c|c|c|c|c|c|}
\hline \multirow{2}{*}{ Substance } & \multicolumn{4}{|c|}{ BrdU-/B220+ } & \multicolumn{4}{|c|}{ BrdU-/CD3+ } \\
\cline { 2 - 9 } & $(\%)$ & Index & $\left(\times 10^{4}\right)$ & Index & $(\%)$ & Index & $\left(\times 10^{4}\right)$ \\
\hline \hline AOO & $16.89 \pm 6.67$ & 1.00 & $34.83 \pm 25.03$ & 1.00 & $74.53 \pm 4.60$ & 1.00 & $142.34 \pm 37.51$ & 1.00 \\
$0.01 \%$ DNCB & $23.76 \pm 4.35 *$ & 1.41 & $97.00 \pm 61.17$ & 2.78 & $69.07 \pm 2.83$ & 0.93 & $276.69 \pm 187.89$ & 1.94 \\
$0.05 \%$ DNCB & $21.17 \pm 1.98$ & 1.25 & $137.01 \pm 45.44$ & 3.93 & $67.54 \pm 4.77 *$ & 0.91 & $448.89 \pm 176.92$ & 3.15 \\
$0.25 \%$ DNCB & $32.73 \pm 3.29 * *$ & 1.94 & $909.78 \pm 537.46 * * 26.12$ & $48.83 \pm 2.98 * *$ & 0.66 & $1373.37 \pm 849.51 * * \mid$ & 9.65 \\
& & & & & & & & \\
$2.50 \%$ Benzocaine & $17.54 \pm 1.07$ & 1.04 & $65.67 \pm 27.77$ & 1.91 & $76.86 \pm 4.71$ & 1.03 & $284.38 \pm 115.63$ & 2.00 \\
$5.00 \%$ Benzocaine & $17.29 \pm 5.02$ & 1.02 & $90.81 \pm 66.19$ & 2.61 & $74.57 \pm 5.95$ & 1.00 & $349.11 \pm 161.76 *$ & 2.45 \\
$10.00 \%$ Benzocaine & $20.92 \pm 4.18$ & 1.24 & $57.89 \pm 10.55$ & 1.67 & $74.85 \pm 3.92$ & 1.00 & $211.57 \pm 48.41$ & 1.49 \\
\hline
\end{tabular}

Each value represents the mean \pm S.D.. \% represents the cell percentages. $\times 10^{4}$ represents multiplication of the number of cells by 10000. Index is the ratio of the mean of actual measurements for each test substance treatment group versus that of the AOO treatment control group. Each test substance treatment group and the AOO treatment control group were compared by Dunnett's multiple comparison. $*$ : $\mathrm{p}<0.05, * *: \mathrm{p}<0.01$.

dent standard LLNA, using the strong sensitizer DNCB and the weak sensitizer benzocaine.

In our study, non-radioisotope methods (BrdU ex vivo and in vivo incorporation, IL-2 production and PCNA expression) detected statistically significant increases in the $0.25 \%$ DNCB groups, as did the standard radioisotope method. Sensitization rate of DNCB was $100 \%$ in GPMT and it was classified as an extreme sensitizer (Basketter and Scholes, 1992). Some authors have stated that DNCB at doses of $0.1 \%$ and $0.25 \%$ is positive in the standard LLNA (Kimber et al., 1989, 1991; Loveless et al., 1996; Gerberick et al., 1999a).
The BrdU ex vivo method detected statistically significant increases in the 5\% and $10 \%$ benzocaine groups in one laboratory. The BrdU in vivo method detected statistically significant increases in the $2.5 \%$, $5 \%$ and $10 \%$ benzocaine groups in one laboratory, but dose-dependent increases were not evident. Measuring IL-2 production detected statistically significant increases in the $5 \%$ benzocaine group. However, a dose-dependent response was not observed with any method used. In some experiments, there was an indication toward a bell-shaped dose response curve for benzocaine (Kimber et al., 1991; Basketter et al., 1994, 1995; Warbrick et al., 2000; Van Och et al., 2000). 
LLNA with non-radioisotope alternative endpoints.

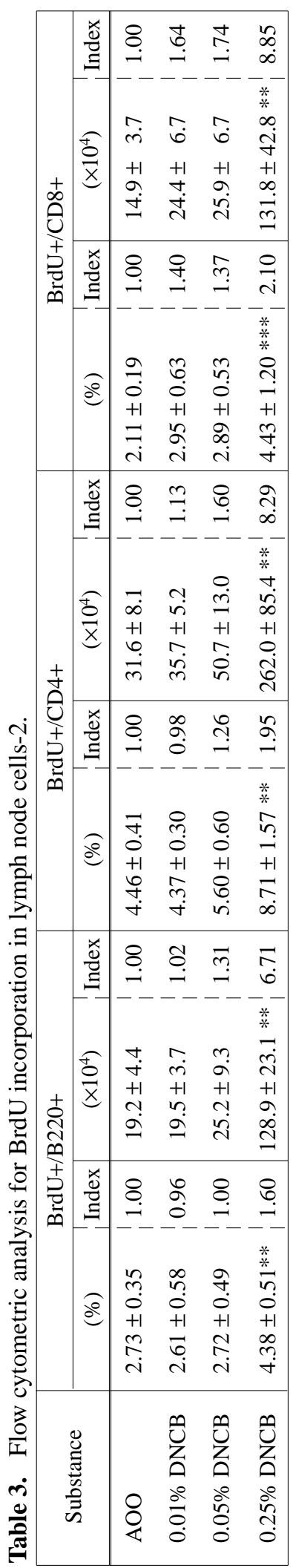

톨용

$\stackrel{\mathscr{E}}{\Xi}$

范 吾

芯 范

홈

$\stackrel{\vec{E}}{x}$

党

$\dot{8}$

¿

긍

焉

등

可

当

()

둥

응

등

完 焉

当

苞 8

흥 월

5

×

sis

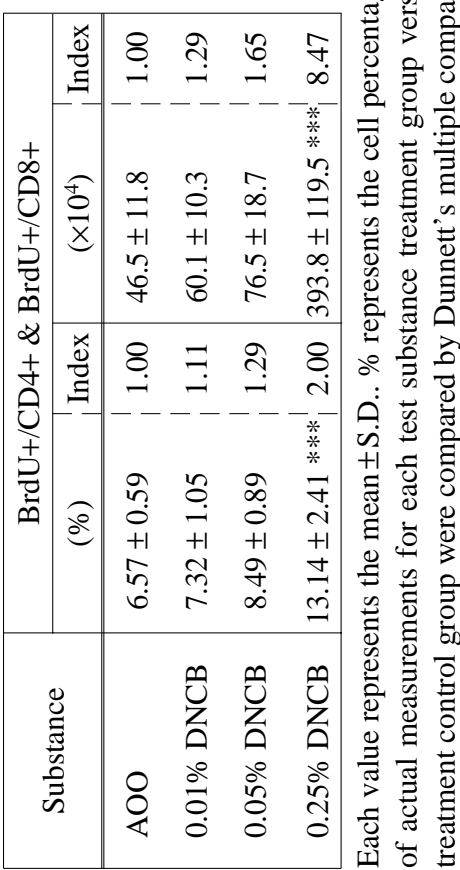

Vol. 27 No. 3 
A. SUDA et al.

\begin{tabular}{|c|c|c|c|c|c|c|c|c|c|c|}
\hline \multirow{4}{*}{ 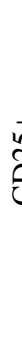 } & $\begin{array}{l}\stackrel{\times}{\Xi} \\
\Xi\end{array}$ & $\stackrel{8}{-}$ & $\begin{array}{l}\infty \\
\stackrel{0}{0} \\
0\end{array}$ & กี & $\overrightarrow{\widetilde{\sigma}}$ & $\underset{\text { ¿ }}{8}$ & $\stackrel{\text { oे }}{\text {. }}$ & ָ̦ & $\underset{-}{8}$ & $\underset{\underline{0}}{\overrightarrow{0}}$ \\
\hline & $\frac{\tilde{\sigma}}{\bar{x}}$ & $\mathscr{\infty}_{\infty}$ & $\begin{array}{l}0 \\
\dot{r}\end{array}$ & $\grave{\varrho}$ & $\stackrel{n}{n}$ & $\stackrel{n}{r}$ & $\underset{\infty}{\sim}$ & $\vec{a}$ & $\stackrel{n}{r}$ & to \\
\hline & i & $\stackrel{8}{-}$ & $\hat{\sigma}$ & $\exists$ & 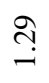 & $\underset{-}{8}$ & $\stackrel{t}{0}$ & $\stackrel{\bullet}{\stackrel{-}{*}}$ & $\stackrel{\sigma}{\sigma}$ & \\
\hline & @ & $\stackrel{\infty}{n}$ & ले & 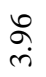 & $\underset{+}{+}$ & $\stackrel{\leftrightarrow}{m}$ & $\stackrel{\Re}{r}$ & $\stackrel{\vartheta}{\stackrel{+}{+}}$ & $\underset{\stackrel{\sigma}{\sigma}}{\stackrel{+}{+}}$ & 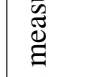 \\
\hline & 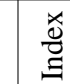 & $\underset{-}{8}$ & $\stackrel{N}{\stackrel{0}{0}}$ & $\stackrel{?}{+}$ & $\frac{0}{a}$ & $\underset{-}{8}$ & $\stackrel{\infty}{=}$ & 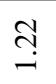 & $\stackrel{n}{0}$ & E \\
\hline & $\frac{\bar{\sigma}}{x}$ & $\bar{\lambda}$ & $\bar{n}$ & iे & 宫 & $\stackrel{\infty}{=}$ & $\begin{array}{l}- \\
\dot{I}\end{array}$ & $\stackrel{n}{+}$ & $\stackrel{\vec{d}}{\mathrm{i}}$ & \\
\hline \multirow[t]{2}{*}{$\infty$} & $\frac{\vec{x}}{0}$ & $\underset{8}{\stackrel{-}{-}}$ & $\stackrel{\infty}{\stackrel{0}{0}}$ & $\cong$ & $\stackrel{\overbrace{}}{i}$ & $\underset{\sim}{\stackrel{8}{0}}$ & $\underset{\text { Sa }}{-}$ & $\stackrel{\infty}{\stackrel{\infty}{\leftrightarrow}}$ & $\stackrel{\circ}{-}$ & \\
\hline & 8 & $\frac{5}{a}$ & $\stackrel{\sigma}{\circ}$ & $\stackrel{尺}{\stackrel{0}{0}}$ & $\begin{array}{l}\stackrel{8}{0} \\
\stackrel{\text { ¿ }}{1}\end{array}$ & กู & ڤై & & $\begin{array}{l}\infty \\
0 \\
0 \\
0\end{array}$ & \\
\hline \multirow{4}{*}{ 文 } & 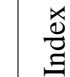 & $\stackrel{8}{\stackrel{8}{\circ}}$ & $\stackrel{\Re}{0}$ & $\stackrel{\infty}{\stackrel{\infty}{\hookrightarrow}}$ & 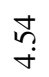 & $\underset{\text { \& }}{\text {. }}$ & $\Xi$ & $\exists$ & $\begin{array}{l}n \\
o \\
0\end{array}$ & \\
\hline & $\begin{array}{l}\overline{\tilde{c}} \\
\bar{x}\end{array}$ & 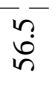 & $\frac{n}{\gamma}$ & $\overline{\mathrm{i}}$ & 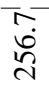 & in & $\begin{array}{l}\infty \\
\infty \\
\infty \\
\infty\end{array}$ & : & $\begin{array}{l}-0 \\
\dot{n} \\
i\end{array}$ & \\
\hline & $\begin{array}{l}\stackrel{x}{\Xi} \\
\Xi\end{array}$ & $\stackrel{8}{\circ}$ & $\underset{.}{.}$ & $\stackrel{s}{.}$ & $\stackrel{\infty}{\circ}$ & $\underset{\text { \& }}{\text {. }}$ & $\underset{\sim}{\vec{r}}$ & $\stackrel{\infty}{\stackrel{0}{0}}$ & $\hat{a}$ & \\
\hline & $\widehat{d}$ & $\begin{array}{l}n \\
\stackrel{n}{n} \\
\dot{n}\end{array}$ & $\stackrel{\vec{d}}{\dot{d}}$ & $\begin{array}{l}\text { तु } \\
\text { הू }\end{array}$ & $\begin{array}{l} \\
\dot{d} \\
\dot{d}\end{array}$ & 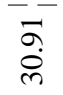 & 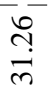 & $\begin{array}{l}\infty \\
\stackrel{\infty}{0} \\
\stackrel{p}{0}\end{array}$ & $\bar{a}$ & \\
\hline \multirow{4}{*}{ 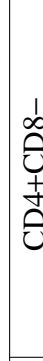 } & $\begin{array}{l}\stackrel{\star}{0} \\
\stackrel{0}{\Xi}\end{array}$ & $\underset{-}{8}$ & $\stackrel{\Re}{0}$ & $\stackrel{m}{=}$ & $\stackrel{n}{r}$ & $\underset{8}{8}$ & $\stackrel{9}{\leftrightarrows}$ & $\stackrel{9}{\leftrightarrows}$ & $\stackrel{+}{0}$ & \\
\hline & {$\left[\begin{array}{l}\tilde{\delta} \\
\bar{x}\end{array}\right.$} & $\begin{array}{l}0 \\
\dot{0} \\
\dot{g}\end{array}$ & ชิ & 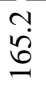 & ñ & $\begin{array}{l}0- \\
\stackrel{0}{\varrho}\end{array}$ & $\begin{array}{l}0 \\
i \\
\end{array}$ & $\vec{m}$ & $\begin{array}{c}0 \\
\ddot{\Xi} \\
=\end{array}$ & 5 \\
\hline & $\stackrel{x}{\stackrel{0}{\Xi}}$ & $\stackrel{8}{-}$ & $\stackrel{8}{-}$ & $\dddot{n}$ & $\infty_{0}^{\infty}$ & $\underset{-}{8}$ & ڤ̆ & $\hat{o}$ & $\hat{a}$ & \\
\hline & $\stackrel{9}{9}$ & ले & $\frac{9}{8}$ & 8 & $\begin{array}{l}n \\
\text { in } \\
\text { nn }\end{array}$ & مิ & $\begin{array}{l}0 \\
\delta \\
\delta\end{array}$ & 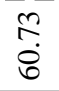 & $\begin{array}{l}0 \\
2 \\
8\end{array}$ & \\
\hline & $\begin{array}{l}\stackrel{\widehat{J}}{\Xi} \\
\end{array}$ & $\stackrel{8}{\circ}$ & $\stackrel{t}{\stackrel{0}{0}}$ & $\underset{ָ}{\tilde{I}}$ & $\underset{\forall}{\stackrel{J}{*}}$ & $\underset{8}{8}$ & $\stackrel{\bullet}{\leftrightarrows}$ & $\stackrel{m}{\longrightarrow}$ & $\begin{array}{l}\stackrel{\circ}{0} \\
\stackrel{0}{0}\end{array}$ & \\
\hline \multirow{3}{*}{ 苞 } & 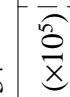 & $\overline{\mathrm{d}}$ & 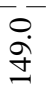 & 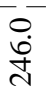 & $\begin{array}{l}\infty \\
\infty \\
\infty \\
\infty\end{array}$ & $\begin{array}{l}\text { बे- } \\
\text { હे }\end{array}$ & 吕 & $\begin{array}{l}n \\
2 \\
ٌ\end{array}$ & àd & \\
\hline & $\frac{\times}{\tilde{g}}$ & $\stackrel{8}{-}$ & Б) & $\underset{\text { So }}{ }$ & $\begin{array}{l}0 \\
\infty \\
0\end{array}$ & $\underset{-}{\stackrel{8}{2}}$ & $\underset{-}{\stackrel{8}{-}}$ & ळ. & $\underset{-}{\stackrel{\&}{i}}$ & \\
\hline & 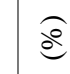 & $\underset{\infty}{\stackrel{\infty}{\infty}}$ & $\begin{array}{l}\hat{b} \\
\infty \\
\infty\end{array}$ & $\begin{array}{l}\bar{\sigma} \\
\dot{\infty}\end{array}$ & $\begin{array}{l}8 \\
i n\end{array}$ & $\frac{\tilde{n}}{2}$ & $\frac{\widehat{亏}}{\vec{n}}$ & ڤे & $\stackrel{+}{m}$ & \\
\hline & 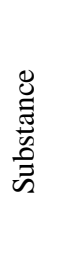 & 足 & $\begin{array}{l}0 ै \\
z \\
0 \\
0 \\
0 \\
0\end{array}$ & 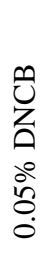 & 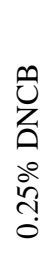 & 8 & 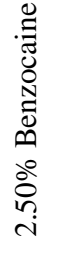 & 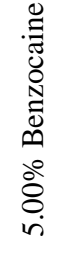 & $\begin{array}{l}0 \\
\tilde{\Xi} \\
0 \\
0 \\
\bar{\Xi} \\
\infty \\
0 \\
0 \\
0 \\
0 \\
0\end{array}$ & 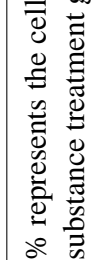 \\
\hline
\end{tabular}


LLNA with non-radioisotope alternative endpoints.

Table 5. Flow cytometric analysis for B220+/I-A+ and CD69+/I-A+ cells in lymph nodes.

\begin{tabular}{|l|r|c|c|c|}
\hline \multirow{2}{*}{ Substance } & \multicolumn{2}{|c|}{ B220+/I-A+ } & \multicolumn{2}{c|}{ CD69+/I-A+ } \\
\cline { 2 - 5 } & $(\%)$ & Index & $(\%)$ & Index \\
\hline \hline AOO & 8.54 & 1.00 & 1.34 & 1.00 \\
$0.13 \%$ DNCB & 8.41 & 0.98 & 1.99 & 1.51 \\
$0.25 \%$ DNCB & 16.16 & 1.85 & 3.40 & 2.50 \\
$0.50 \%$ DNCB & 17.39 & 1.97 & 6.28 & 4.62 \\
\hline
\end{tabular}

$\%$ represents the cell percentages. Index is the ratio of the mean of actual measurements for each test substance treatment group versus that of the AOO treatment control group.

This could be due to local toxicity or other inhibitory effects, dependent on the potential of benzocaine to act as a local anesthetic, or a direct effect on local blood vessels with dose-dependent changes in skin clearance of benzocaine (Basketter et al., 1995). OECD Test Guideline 406 (1992) recommended a regular 6-month evaluation of 1 of 3 moderately-sensitizing positive control substances, hexylcinnamic aldehyde (HCA), mercaptobenzothiazole (MBT) and benzocaine. Sensitization rates of benzocaine are $19 \%$ and $50 \%$ in human maximization test and GPMT, respectively (Kligman, 1966; Basketter and Scholes, 1992). In previous reports, benzocaine has given highly variable and equivocal results in LLNA (Kimber et al., 1989; Kimber et al., 1991; Basketter et al., 1994; Warbrick et al., 2000; Van Och et al., 2000). Therefore, Basketter et al. (1995) concluded that benzocaine is not a suitable positive control for use in predictive tests for skin sensitization. OECD Test Guideline 429 (2000) accepted LLNA as a stand-alone skin sensitization test, and recommended HCA and MBT as positive controls, but not benzocaine. We used benzocaine as a weak sensitizer to compare non-radioisotope methods and the radioisotope-dependent standard LLNA.

The standard LLNA has the disadvantages of technical difficulties for $3 \mathrm{H}-\mathrm{TdR}$ injection into the tail vein of the brown CBA mice and for disposal of the radioisotope-contaminated animals. Therefore, several methods without using any radioisotope are advantageous for the practical LLNA application.

Boussiquet-Levoux et al. (1995) histologically observed proliferative responses of LNC in LLNA using BrdU. However, this method may not be quantitatively so accurate as the original LLNA, since cell counting under microscopic observation is required. In the BrdU in vivo method, BrdU positive cells are counted using a flow cytometer, which is more accurate. Furthermore, 2-color staining in FCM analysis can reveal a proliferating $\mathrm{LNC}$ subset.

The IL-2 assay is closely related to T cell proliferation which plays an important role in the induction of Type IV allergy. In contrast, in vivo $3 \mathrm{H}-\mathrm{TdR}$ incorporation tends to reflect not only the proliferation of $\mathrm{T}$ cells but also an unidentified proliferation of other cells in lymph nodes. Hatao et al. (1995) reported that the amount of IL-2 was increased by strong sensitizers such as oxazolone, TNBS, hydroquinone, cinnamaldehyde, Sudan I, PPDA as well as the moderate sensitizer, citral, but was not increased by moderate sensitizer eugenol. In the present study, 0.25\% DNCB and $5 \%$ benzocaine significantly increased IL-2 production. These results suggest that this method can detect a wider range of skin sensitizers.

PCNA is constitutively expressed during the $S$ phase of mitosis. Kuhn et al. (1995) described the good correlation between the incorporation of $3 \mathrm{H}-\mathrm{TdR}$ and the nuclear expression of PCNA in LLNA. They stated that the total population of PCNA positive cells was significantly increased after application of contact sensitizers (DNFB, TNCB, oxazolone) in comparison to solvent-treated mice (Kuhn et al., 1995). In addition, they stained LNC of mice treated with oxazolone for PCNA and the T cell markers CD4 and CD8. As a result, the majority of PCNA-positive cells belonged to the CD4-positive T cell subsets. These data show that skin sensitization potential can be accurately evaluated by PCNA expression without the technical limitations associated with the use of radioisotopes, and a more detailed view of the immune response induced by allergens can be obtained. In our study, although no combined staining was performed, the SI of the $0.25 \%$ DNCB group was high.

Many investigators have examined the FCM analysis of proliferating cells in LLNA. Sikorski et al. (1996) reported that the percentage of B220-positive cells increased dose-dependently in response to allergenic chemicals (TNCB, DNCB). The strong sensitizer DNCB induced significant increases in CD3 positive cells and CD25-positive cells compared with vehicle control and irritant SDS (De Silva et al., 1993). In our study, FCM analysis data showed that SIs of the percentage of B220-positive cells and CD25-positive cells in the $0.25 \%$ DNCB group were 2.25 and 1.29 , respectively.

The IMDS method can differentiate between irritative and allergic skin reactions based on cellularity index and ear swelling index. In our study, since DI 
A. SUDA et al.

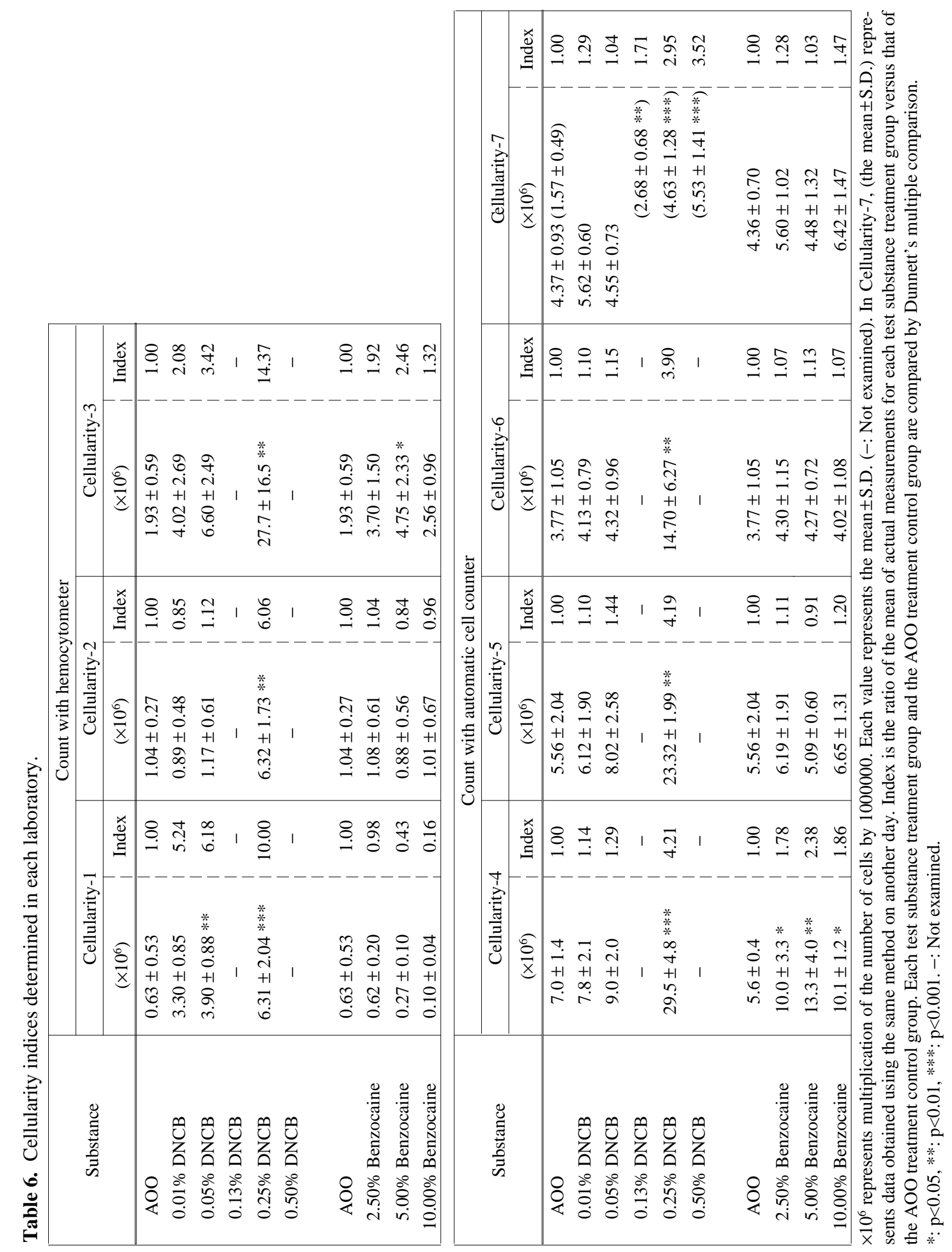

Vol. 27 No. 3 
LLNA with non-radioisotope alternative endpoints.

showed values $>1$ for all concentrations tested, DNCB is an allergic compound, as supported by the results of FCM analysis, i.e., increases in B220+/I-A+ cells (B cell) and CD69+/I-A+ cells (activated B cell) were observed (Table 5). Homey et al. (1998) reported that the most prominent differences between irritant and allergic reactions were seen for the expression of CD69+/I-A+ lymph node cells. Allergen (oxazolone) treatment dramatically upregulated CD69 on I-A+ lymph node cells. On the other hand, an irritant (croton oil) failed to induce significant changes in CD69 expression. Similar results were obtained for the expression of B220+/I-A+ lymph node cells. They concluded that if a test chemical produced a DI of 1 , further studies such as FCM analysis of cell surface markers were needed.

In conclusion, our data suggest that BrdU data obtained ex vivo and in vivo and measuring IL-2 production are sensitive and useful methods. The decision process to identify a positive response in the LLNA standard method should include a SI $\geq 3$, statistical significance and dose response information (NIH Publication, 1999). On the other hand, non-radioisotope methods do not yet have the standard of a positive response. In our study, we considered the statistical significance when making a judgement. We believe that these non-radioisotope methods to assess allergic contact dermatitis caused by chemicals can be used even in a laboratory where it can be difficult to handle radioisotopes.

\section{ACKNOWLEDGMENT}

We thank Drs. T. Matsuzawa (Yamanouchi Pharmaceutical Co., Ltd.) for valuable advice and encouragement, and K. Yamashita (GlaxoSmithKline K.K.), H. Toyota (GlaxoSmithKline K.K.), M. Hino (Shionogi \& Co., Ltd.) and Y. Iwaki (Taisho Pharmaceutical Co., Ltd.) for technical support.

\section{REFERENCES}

Basketter, D.A. and Scholes, E.W. (1992): Comparison of the local lymph node assay with the guinea pig maximization test for the detection of a range of contact allergens. Food Chem. Toxicol., 30, 65-69.

Basketter, D.A., Scholes, E.W. and Kimber, I. (1994): The performance of the local lymph node assay with chemicals identified as contact allergens in the human maximization test. Food Chem. Toxicol., 32, 543-547.
Basketter, D.A., Scholes, E.W., Wahlkvist, H. and Montelius, J. (1995): An evaluation of the suitability of benzocaine as a positive control skin sensitizer. Contact Derm., 33, 28-32.

Basketter, D.A., Gerberick, G.F., Kimber, I. and Loveless, S.E. (1996): The local lymph node assay - a viable alternative to currently accepted skin sensitisation tests. Food Chem. Toxicol., 34, 985-997.

Basketter, D.A., Gerberick, G.F. and Kimber, I. (1998): Strategies for identifying false positive responses in predictive sensitization tests. Food Chem. Toxicol., 36, 327-333.

Boussiquet-Leroux, C., Durand-Cavagna, G., Herlin, K. and Holder, D. (1995): Evaluation of lymphocyte proliferation by immunohistochemistry in the local lymph node assay. J. Appl. Toxicol., 15, 465-475.

Chamberlain, M. and Basketter, D.A. (1996): The local lymph node assay: Status of validation. Food Chem. Toxicol., 34, 999-1002.

Dearman, R.J., Scholes, E.W., Ramdin, L.S.P., Basketter, D.A. and Kimber, I. (1994): The local lymph node assay: An interlaboratory evaluation of interleukin 6 (IL-6) production by draining lymph node cells. J. Appl. Toxicol., 14, 287291.

De Silva, O., Perez, M.J., Pineau, N., Rougie, A. and Dossou, K.G. (1993): Local lymph node assay: Study of the in vitro proliferation and control of the specificity of the response by FACScan analysis. Toxicol. In Vitro, 7, 299-303.

Dunnett, C.W. (1955): A multiple comparison procedure for comparing several treatments with a control. J. Am. Stat. Assoc., 12, 1096-1121.

Gerberick, G.F., Cruse, L.W., Miller, C.M., Sikorski, E.E. and Ridder, G.M. (1997): Selective modulation of $\mathrm{T}$ cell memory markers CD62L and CD44 on murine draining lymph node cells following allergen and irritant treatment. Toxicol. Appl. Pharmacol., 46, 1-10.

Gerberick, G.F., Cruse, L.W. and Ryan, C.A. (1999a): Local lymph node assay: Differentiating allergic and irritant responses using flow cytometry. Methods, 19, 48-55.

Gerberick, G.F., Cruse, L.W., Miller, C.M. and Ridder, G.M. (1999b): Selective modulation of B-cell activation markers CD86 and $\mathrm{I}-\mathrm{A}^{\mathrm{k}}$ on murine draining lymph node cells following allergen or irritant treatment. Toxicol. Appl. Pharmacol., 159, 142-151. 
Hariya, T., Hatao, M. and Ichikawa, H. (1999): Development of a non-radioactive endpoint in a modified lymph node assay. Food Chem. Toxicol., 37, 87-93.

Hatao, M., Hariya, T., Katsumura, Y. and Kato, S. (1995): A modification of local lymph node assay for contact allergenicity screening: Measurement of interleukin-2 as an alternative to radioisotope-dependent proliferation assay. Toxicology, 98, 15-22.

Homey, B., Von Schilling, C., Blumel, J., Schuppe, H. C., Ruzicka, T., Ahr, H.J., Lehmann, P. and Vohr, H.W. (1998): An integrated model for the differentiation of chemical-induced allergic and irritant skin reactions. Toxicol. Appl. Pharmacol., 153, 83-94.

Kimber, I., Hilton, J. and Weisenberger, C. (1989): The murine local lymph node assay for identification of contact allergens: A preliminary evaluation of in situ measurement of lymphocyte proliferation. Contact Derm., 21, 215-220.

Kimber, I., Hilton, J., Botham, P.A., Basketter, D.A., Scholes, E.W., Miller, K., Robbins, M.C., Harrison, P.T.C., Gray, T.J.B. and Waite, S.J. (1991): The murine local lymph node assay: Results of an inter-laboratory trial. Toxicol. Lett., 55, 203-213.

Kligman, A.M. (1966): The identification of contact allergens by human assay. III. The maximization test: A procedure for screening and rating contact sensitizers. J. Invest. Derm., 47, 393-409.

Kuhn, U., Lempertz, U., Knop, J. and Becker, D. (1995): A new method for phenotyping proliferating cell nuclear antigen positive cells using flow cytometry: Implications for analysis of the immune response in vivo. J. Immunol. Meth., 179, 215-222.

Loveless, S.E., Ladics, G.S., Gerberick, G.F., Ryan, C.A., Basketter, D.A., Scholes, E.W., House,
R.V., Hilton, J., Dearman, R.J. and Kimber, I. (1996): Further evaluation of the local lymph node assay in the final phase of an international collaborative trial. Toxicology, 108, 141-152.

NIH Publication (1999): The murine local lymph node assay: A test method for assessing the allergic contact dermatitis potential of chemicals/compounds. No. 99-4494.

OECD Guideline 406 (1992): Skin sensitization.

OECD Guideline 429 (2000): Skin sensitization: local lymph node assay.

Penit, C. and Vasseur, F. (1993): Phenotype analysis of cycling and postcycling thymocytes: Evaluation of detection methods for BrdUrd and surface proteins. Cytometry, 14, 757-763.

Sikorski, E.E., Gerberick, G.F., Ryan, C.A., Miller, C.M. and Ridder, G.M. (1996): Phenotypic analysis of lymphocyte subpopulations in lymph nodes draining the ear following exposure to contact allergens and irritants. Fund. Appl. Toxicol., 34, 25-35.

Van Och, F.M., Slob, W., De Jong, W.H., Vandebriel, R.J. and Van Loveren, H. (2000): A quantitative method for assessing the sensitizing potency of low molecular weight chemicals using a local lymph node assay: Employment of a regression method that includes determination of the uncertainty margins. Toxicology, 146, 49-59.

Vohr, H.W., Blumel, J., Blotz, A., Homey, B. and Ahr, H.J. (2000): An intra-laboratory validation of the integrated model for the differentiation of skin reactions (IMDS): Discrimination betweeen (photo) allergic and (photo) irritant skin reactions in mice. Arch. Toxicol., 73, 501509.

Warbrick, E.V., Dearman, R.J., Basketter, D.A. and Kimber, I. (2000): Failure of vehicle to influence local lymph node assay response to benzocaine. Contact Derm., 42, 164-165. 